\title{
Effect of academic stress on serum cortisol level and CD4 cell count in young male postgraduate students in Okada, Nigeria
}

\author{
F.A. EHIAGHE ${ }^{1,2,3^{*}}$, D.E. AGBONLAHOR ${ }^{2,4}$, M. I. OSITADIMA ${ }^{3}$, I.J. EHIAGHE ${ }^{2,3}$ and \\ H.B. OSADOLOR ${ }^{5}$ \\ ${ }^{1}$ Department of Hematology, College of Health Sciences, Igbinedion University, Okada, Nigeria. \\ ${ }^{2}$ Lahor Research and Medical Centre, 121, Old Benin-Agbor Road, Benin City, Nigeria. \\ ${ }^{3}$ Department of Medical Laboratory Science, Nnamdi Azikiwe University, Awka, Nigeria. \\ ${ }^{4}$ Department of Medical Laboratory Science, College of Health Sciences Niger Delta University, \\ Wilberforce Island, Amassoma, Bayelsa State, Nigeria. \\ ${ }^{5}$ Department of Medical Laboratory Science, University of Benin, Benin City, Nigeria. \\ *Author corresponding; E-mail: fredleo2547@yahoo.com
}

\begin{abstract}
To assess the effect of stress on serum cortisol level and CD4 cell count in young male postgraduate students at Igbinedion University, a cross sectional laboratory based analysis survey was adopted for this study. A total of 104 male volunteer postgraduate students (age $22 \pm 7.0$ years, body mass index $26 \pm 0.5 \mathrm{~kg} / \mathrm{m}^{2}$ ) were randomly recruited. Total white blood cell (TWBC) was determined using the Sysmex ${ }^{\circledR}$ Automated Hematology Analyzer. CD4 cell count was estimated using Partec cyflow counter. Serum cortisol level was determined by enzyme-linked immunosorbent assay (ELISA) technique. It was observed that there was a significant $(\mathrm{P}<0.05)$ increase in the serum cortisol level at stage $\mathrm{A}\left(1^{\text {st }}\right.$ day of the semester $)$ when compared with stage $\mathrm{B}$ (midway in the semester) and $\mathrm{C}$ (morning of the examination), while there was significant $(\mathrm{P}<$ 0.05) decrease in the TWBC count and CD4 cell count at A stage when compared with stage B and C. It was observed that academic stress was inhibitory of the proliferation of CD4 cells with the elevation of serum cortisol as a possible mediator.
\end{abstract}

() 2014 International Formulae Group. All rights reserved.

Keywords: Stress, cortisol, CD4 cell, ELISA.

\section{INTRODUCTION}

Neuroscientists such as Bruce McEwen and Jaap Koolhaas believe that stress should be restricted to conditions where an environmental demand exceeds the natural regulatory capacity of an organism (Koolhaas, 2011). Several stressors had been associated with a shift in cytokines production toward an anti-inflammatory pattern with cortisol as the proposed mediator (Elenkor and Chrousos, 2002). Cortisol elevation is one way the brain instructs the body to attempt to regain homeostasis by redistributing glucose to areas of the body that need it most (Heart and Brain) (Michael et al., 2001).

It is generally accepted that CD4 T lymphocytes plays a central role in immune response, cellular immune deficiencies of 
these cells may lead to increased susceptibility to infection from viruses, fungi, intracellular bacteria and protozoa (Abbas et al., 2000).

Prolong strenuous exercise has been shown to decrease the number of $\mathrm{T}$ lymphocytes, which might be linked to high plasma level of cortisol (Elenkor and Chrousos, 2002). This study was designed to assess the effect of academic stress on serum cortisol level and CD4 cell count in young male postgraduate students at Igbinedion University, Okada, Nigeria.

\section{MATERIALS AND METHODS \\ Study area}

The study was carried out between March 2011 and March 2012 in the Department of Hematology, College of Health Sciences, Igbinedion University, Okada, Edo State, Nigeria.

\section{Study design}

A cross sectional laboratory based analysis survey was adopted for this study. A total of 104 male volunteer postgraduate students (age $25 \pm 7.0$ years, body mass index $26 \pm 0.5 \mathrm{~kg} / \mathrm{m}^{2}$ ) were randomly recruited. The participant gave informed consent while the Board of ethical committee approved the study design. $5 \mathrm{ml}$ of venous blood was taken from the antecubital vein by venapuncture on the $1^{\text {st }}$ day they resume the semester, midway in the semester and on the morning of the examination day. It was shared equally into an ethylene diamine tetra acetic acid (EDTA) container for total white blood cell count and CD4+ cell estimation. The other portion was transferred into an anticoagulant free test tube and allow clot, subsequently centrifuge at 750 $\mathrm{x} g$ for 15 minutes to obtain serum. The serum was immediately aliquoted into an eppendorf tubes place on ice and immediately stored at $80{ }^{\circ} \mathrm{C}$ until serum cortisol was evaluated.

\section{Exclusion criteria}

- Those who abuse alcohol were excluded.

- Young male less than 18 years of age and those greater than 32 years of age were excluded.

- Young male with any underlying history of illness were excluded.

- Professional athletes were excluded.

- Young male on performance enhancing drugs were excluded.

- Those who are sexually active were excluded.

- Those with hemoglobin concentration of less than $13.0 \mathrm{~g} / \mathrm{dl}$ and above $17.5 \mathrm{~g} / \mathrm{dl}$ were excluded.

- Those with any detectable viral, bacterial and parasitic infection were excluded.

- Those who engage in strenuous activity were excluded

- Those with 9.00 am serum cortisol level of above $25 \mu \mathrm{g} / \mathrm{dl}$ were excluded.

- Those currently on any medication were excluded.

\section{Evaluation of parameters}

\section{Total white blood cell estimation}

Total white blood cell was determined using the sysmex ${ }^{\circledR}$ Automated Hematology Analyzer Kx-2IN, sysmex corporation, KobeJapan. It employs WBC detector block and WBC lyse reagent to measure WBC count as described by Samuel et al. (2006).

\section{CD4 cell estimation}

CD4 cell count was estimated using Partec cyflow counter for the quantification of CD4 T lymphocytes as described by PCC (2010).

\section{Serum cortisol estimation}

Serum cortisol level was determined by enzyme linked immune sorbent assay technique. This test kit operates on the basis of competition between the hormone conjugate and the cortisol in the sample for a limited number of binding sites on the 
antibody coated plate. Twenty micro liters of standard or sample(s) was added per microplate. $200 \mu$ l cortisol hormone conjugate was added to the standard or sample(s) and covered with a sealing tape. It was incubated at room temperature for 1 hour. The solution was discarded and microplates washed three times with $300 \mu \mathrm{l}$ of $1 \mathrm{X}$ wash solution. $100 \mu \mathrm{l}$ of Tetramethylbenzidine one step substrate was added to each microplate and incubated for 15 minutes at room temperature in the dark with gentle shaking. $100 \mu \mathrm{l}$ of stop solution was added to each microplate. The intensity of the color developed was measured at $450 \mathrm{~nm}$ wavelength using stat fax ${ }^{\circledR} 4700$ micro strip reader. This method has been previously described by Ehiaghe et al. (2013).

\section{Statistical analysis}

All numerical data were presented as mean \pm standard deviation and analyzed using one way analysis of variance (ANOVA) and Turkey - Kramer Multiple comparison test using SPSS - 18.0 statistical program. P values $<0.05$ were considered significant.

\section{RESULTS}

Table 1 shows the mean \pm standard of total white blood cell count, CD4+ cell count and serum cortisol level at stage A, B and C. It was observed that, there was a significant $(\mathrm{P}<0.05)$ increase in the serum cortisol level at stage A when compared with stage $B$ and $C$, while there was significant $(\mathrm{P}$ $<0.05)$ decrease in the TWBC count and CD4+ cell count at A stage when compared with stage $\mathrm{B}$ and $\mathrm{C}$.

\section{DISCUSSION}

The significant increase in serum cortisol level coupled with the reduction in CD4 cell count and Total white blood cells in stage $\mathrm{C}$ as compared in stage $\mathrm{B}$ and A (Table 1). This could be attributed to the effect of prolonged cortisol secretion from the adrenal cortex which could be linked to academic stress. This is in accordance with the finding of Scott (2011), where cortisol is released in response to stress, sparing available glucose for the brain and heart, generating new energy from stored reserves and diverting energy from low priority organ in other to survive the immediate threats. However, prolong cortisol secretion may be due to chronic stress resulting in significant physiological changes. It is also in line with these findings.

Table 1: Total white blood cell count, CD4+ cell count and serum cortisol level at stage A, B and C.

\begin{tabular}{lccc}
\hline Parameters & $\begin{array}{c}\mathbf{1}^{\text {st }} \text { day of the } \\
\text { semester }(\mathbf{A})\end{array}$ & $\begin{array}{c}\text { Midway in the } \\
\text { semester }(\mathbf{B})\end{array}$ & $\begin{array}{c}\text { Morning of the } \\
\text { examination }(\mathbf{C})\end{array}$ \\
\hline $\begin{array}{l}\text { Total white Blood cell } \\
\text { count }(\text { cells } / \mu \mathrm{l})\end{array}$ & $10000 \pm 10$ & $6900 \pm 8^{\mathrm{M}}$ & $5800 \pm 8^{\mathrm{N}, \mathrm{O}}$ \\
\hline $\mathrm{CD} 4+$ cell count \\
(cells/ $\mu \mathrm{l})$
\end{tabular}


The immune system is merely responding to the damage done by the stressor, during which most of the adaptation leads to greater fitness, if balance diet and proper resting are observed (Ehiaghe et al., 2013). Moderately intense exercise stimulates the immune system and enhances resistance to infectious disease (Pedersen and HoffmanGoetz, 2000). Stress is the body's reaction to any stimuli that disturbs its homeostasis (Kemeny, 2007). The post exercise immune response is similar to that seen in both infection and inflammation, consisting of neutrophilia and lymphocytopenia (Tauler et al., 2004; Tauler et al., 2006).

Long term exposure to cortisol damages cells in the brain (Hippocampus) which results in learning impairment and inability to retrieve already stored information (De Quervain et al., 2000). Oxidative stress occurs when reactive oxygen species (ROS) and reactive nitrogen species (RNS) production overwhelms the antioxidant defenses system (Gomex et al., 2008). Lymphocytes appear to respond to oxidative stress challenges by increasing antioxidant enzymes. The immune suppression observed following exercise of a strenuous and prolonged nature has been linked to a decrease in circulating lymphocytes and a blunted natural killer cell activity (Pederson and Toft, 2000).

\section{Conclusion}

It was observed that academic stress was inhibitory of the proliferation of CD4+ cells with the elevation of serum cortisol as a possible mediator. The molecular mechanism needs further investigation.

\section{REFERENCES}

Abbas AK, Lichtman AH, Pober JS. 2000. Cellular and Molecular Immunology $\left(4^{\text {th }}\right.$ edn). W.B. Saunders: Philadelphia.
De Quervain DJ, Roosendaal B, Nitsch RM, McGaugh JL, Hock C. 2000. Acute cortisone administration impairs retrieval of long-term declaration memory in humans. Nature Neuroscience, 3(4): 313314.

Ehiaghe AF, Ehiaghe IJ, Igere EB, Iyen IR. 2013. The effects of aqueous extracts of Acalypha Wilkesiana supplementation and Exercise Training on Hematopoietic system in Rats. American Journal of Plant Science, 4: 1834 - 1838.

Ehiaghe FA, Agbonlahor DE, Etikerentse SMO, Osadolor HB. 2013. Effect of exercise induced stress on serum cortisol level and cd4 cell count in rats. African Journal of Cellular Pathology, 1(1):1418.

Elenkor IJ Chrousos E. 2002. Stress hormones, proinflammatory and antiinflammatory Cytokines and autoimmunity. Annals of Academic Science, 966: 290-303.

Gomez - Cabrera MC, Domenech E, Vina J. 2008. Moderate exercise is an antioxidant. Up regulation of antioxidant genes by training. Free Radical Biological Medicine, 44: 126 - 131.

Kemeny ME. 2007. Understanding the interaction between psychosocial stress and immune-related diseases: A stepwise progression. Brain, Behavior and Immunity, 21(8): 1009-1018.

Koolhaas J. 2011. "Stress revisited: A critical evaluation of the stress concept." Neuroscience and Biobehavioural. Reviews, 35: 1291-1301.

Michael DD, George PC, Lorah DD, Lillian B, Karin H, Mitchel A, Penelope K, Frank WP. 2001. Hypothalamic-PituitaryAdrenal Axis Dysregulation in Sexually Abused girls. Journal of Clinical Psychiatry, 62(11): 22-27. 
PCC (Partec Cyflow Counter). 2010. Typical steps of Particle Analysis Using Partec Cyflow Counter, Instrument Operating Manual Partec GmbH OHO-Hann-str 32. PCC: Munster; 5-8.

Pedersen BK, Hoffman-Goetz L. 2000. Exercise and the immune system regulation, integration and adaptation physiological. Review, 80: 1055-1081.

Pederson BK, Toft AD. 2000. Effects of exercise on lymphocytes and cytokines. British Journal of Sport Medicine, 34: $246-251$

Samuel OI, Thomas N, Ernest OU, Imelda NN, Elvis NS, Ifeyinwa E. 2006. Comparison of Hematological parameters Determined by the systemex KX-ZIN Automated Hematology Analyzer and the Manual Count. BMC Clinical Pathology, 10: $3-5$.
Scott E. 2011. Cortisol and Stress: How to stay healthy. Stress about Com/od/stresshealth/a/ cortisol htm, 1129.

Tauler P, Aguilo A, Gimeno, T Guix P, Tur JA, Pons A. 2004. Different effects of exercise tests on the antioxidant enzyme activities in lymphocytes and neutrophils. Journal of Nutritional Biochemistry, 15: $479-484$.

Tauler P, Sureda A, Villa G, Tur JA, Pons A. Cases N, Aguilo A, Rodrigue Z-Marroyo JA, Villa G, Tur JA, Pons A. 2006. Increased lymphocyte antioxidant defenses in response to exhaustive exercise do not prevent oxidative damage. Journal of Nutritional Biochemistry, 17: $665-671$. 